\title{
The Enhancement of $\mathrm{H}_{2} \mathrm{O}_{2} / \mathrm{UV}$ AOPs for the Removal of Selected Organic Pollutants from Drinking Water with Hydrodynamic Cavitation
}

\author{
Matej Čehovin, ${ }^{1,2, *}$ Alojz Medic, ${ }^{2}$ Boris Kompare ${ }^{1, \dagger}$ \\ and Andreja Žgajnar Gotvajn ${ }^{3}$ \\ ${ }^{1}$ Faculty of Civil and Geodetic Engineering, University of Ljubljana, Hajdrihova 28, 1000 Ljubljana, Slovenia \\ ${ }^{2}$ MAK CMC Water Technology Ltd., Tbilisijska ulica 81, 1000 Ljubljana, Slovenia \\ ${ }^{3}$ Faculty of Chemistry and Chemical Technology, University of Ljubljana, Večna pot 113, 1000 Ljubljana, Slovenia \\ * Corresponding author: E-mail: Matej.Cehovin@mak-cmc.si; \\ phone: +386-(0)41-676-020
}

Received: 21-07-2016

\begin{abstract}
Drinking water contains organic matter that occasionally needs to be treated to assure its sufficient quality and safety for the consumers. $\mathrm{H}_{2} \mathrm{O}_{2}$ and UV advanced oxidation processes $\left(\mathrm{H}_{2} \mathrm{O}_{2} / \mathrm{UV}\right.$ AOPs) were combined with hydrodynamic cavitation (HC) to assess the effects on the removal of selected organic pollutants. Water samples containing humic acid, methylene blue dye and micropollutants (metaldehyde, diatrizoic acid, iohexol) were treated first by $\mathrm{H}_{2} \mathrm{O}_{2}$ (dosages from 1 to $12 \mathrm{mg} \mathrm{L}^{-1}$ ) and UV (dosages from 300 to $2800 \mathrm{~mJ} \mathrm{~cm}^{-2}$ ) AOPs alone and later in combination with $\mathrm{HC}$, generated by nozzles and orifice plates $(4,8,18$ orifices). Using $\mathrm{HC}$, the removal of humic acid was enhanced by $5-15 \%$, methylene blue by $5-20 \%$ and metaldehyde by approx. $10 \%$. Under favouring conditions, i.e. high UV absorbance of the matrix (more than $0.050 \mathrm{~cm}^{-1}$ at a wavelength of $254 \mathrm{~nm}$ ) and a high pollutant to oxidants ratio, $\mathrm{HC}$ was found to improve the hydrodynamic conditions in the photolytic reactor, to improve the subjection of the $\mathrm{H}_{2} \mathrm{O}_{2}$ to the UV fluence rate distribution and to enhance the removal of the tested organic pollutants, thus showing promising potential of further research in this field.
\end{abstract}

Keywords: Advanced oxidation, Dissolved Organic Carbon, Hydrogen peroxide, Hydrodynamic cavitation, Methylene Blue, Ultraviolet

\section{Introduction}

Organic matter is omnipresent within the sources of drinking water originating from natural processes. Studies are showing that concentrations of total and dissolved organic carbon (TOC and DOC, respectively) in the sources of drinking water have been actually increasing during the last few decades. ${ }^{1}$ Although water treatment processes are being researched and developed constantly, natural organic matter (NOM) still presents a challenge due to its effects on water during its collection, treatment and distribution: (i) colourisation, smell and "earthy" taste of the

$\dagger$ Prof. Dr. Boris Kompare, Professor of Environmental Engineering; deceased 23 October 2014 water; ${ }^{1}$ (ii) increased demand of chemicals used in water treatment to achieve the treatment goal, since NOM react with the aforementioned chemicals; ${ }^{1,2}$ (iii) formation of complexes with (heavy) metals and organic micropollutants that are more difficult to remove; ${ }^{1,3}$ (iv) formation of oxidation and disinfection by-products (DBPs) - especially with chlorine - which are proven to have harmful (carcinogenic, reproductive etc.) effects on the consumers and are contributing to the formation of biodegradable organic compounds that can result in microbiological growth in the distribution system, potentially decreasing the water quality even below allowed standards. ${ }^{1,2,4}$ The quest of sufficient NOM treatment is therefore almost always present, especially when untreated water contains more than $2 \mathrm{mg} \mathrm{L}^{-1}$ of TOC., ${ }^{2,45}$ 
Synthetic organic compounds (SOCs) originating from various anthropogenic activities induce reactions in the organisms for which no adequate biological response is available seeing that their presence in the environment is relatively new and no mechanism could be developed to adapt to them so quickly. ${ }^{6-8}$ These chemicals show mostly long-term detrimental effects (carcinogenicity, mutagenicity, genotoxicity, disruption of endocrine system etc.), with already very low concentrations in the range of $\mu \mathrm{g}$ $\mathrm{L}^{-1}$ to trigger them; therefore they are called micropollutants. ${ }^{8,6,7}$ Due to the presence of numerous species, their harmful effects are multiplied by the so-called "cocktail effect". ${ }^{9}$ Their persistency in the environment and the bioaccumulation are of further concern, as well as the challenges of drinking and waste water treatment, since they are poorly responsive to the removal by traditional technologies (e.g. coagulation, flocculation, oxidation, filtration, biological treatment etc.). ${ }^{8,6,9}$

Advanced oxidation processes (AOPs) have already been well-researched and practically applied for the treatment of recalcitrant natural and synthetic organic pollutants in drinking water. ${ }^{1,2,4,10}$ Characteristically, they take place by oxidizing chemical species in water matrix with the highly reactive and non-selective hydroxyl radicals $(\mathrm{HO} \cdot)$ which are considered to be the strongest technically applicable oxidants in water treatment with the oxidation potential of $2.81 \mathrm{~V} .{ }^{10}$ For drinking water treatment, $\mathrm{HO} \cdot$ are commonly generated by the combination of strong oxidants, such as ozone $\left(\mathrm{O}_{3}, 2.07 \mathrm{~V}\right)$ and hydrogen peroxide $\left(\mathrm{H}_{2} \mathrm{O}_{2}, 1.78 \mathrm{~V}\right)$ or combination of the latter with the UV irradiation, although with much higher UV dosages than used for disinfection $\left(40 \mathrm{~mJ} \mathrm{~cm}{ }^{-2}\right){ }^{10,11}$ With the advances in the efficiency of the equipment used, $\mathrm{H}_{2} \mathrm{O}_{2} / \mathrm{UV}$ AOPs are nowadays considered both technically and economically attractive for full-scale applications worldwide. ${ }^{1,2,4,6,10}$ Nevertheless, to enhance the treatment efficiency and to reduce material and energy inputs (reduced costs per unit of treated volume) extensive research is dedicated to finding synergistic effects of combined treatment processes or to optimising and intensifying the performance of already established technologies.

Hydrodynamic cavitation (HC) has been intensively researched during the past two to three decades as a potential AOP, as it induces effects typical of very low frequency ultrasound applications (range of $10-20 \mathrm{kHz}$ ) already investigated in details. ${ }^{12,13}$ Cavitation in general represents the formation, growth, cyclic compression and the rarefaction with the terminal implosive collapse of water vapour bubbles inside otherwise homogenous media, due to the decrease of static pressure below vapour pressure caused by changes in flow geometry (hydrodynamic cavitation), ultrasound, boiling, fast moving objects or particles (ship propellers, pumps), laser and similar. ${ }^{14,15}$ When cavitation bubbles collapse, extreme temperatures (up to $5000{ }^{\circ} \mathrm{C}$ inside cavitation bubble) and pressures (approx. 500-1000 bar) can exist locally for micro- to milliseconds. ${ }^{15,16}$ Under these conditions the following reactions can proceed, with the thermal dissociation of water vapour inside cavitation bubble representing the first step (chemical Equation /1/): ${ }^{15}$

$$
\begin{aligned}
& \mathrm{H}_{2} \mathrm{O} \rightarrow \mathrm{H} \bullet+\mathrm{HO} \bullet \\
& \mathrm{O}_{2} \rightarrow 2 \mathrm{O} \bullet \\
& \mathrm{H} \bullet+\mathrm{H}_{2} \mathrm{O} \rightarrow \mathrm{HO} \bullet+\mathrm{H}_{2} \\
& \mathrm{O} \bullet+\mathrm{H}_{2} \mathrm{O} \rightarrow 2 \mathrm{HO} \bullet \\
& \mathrm{H} \bullet+\mathrm{O}_{2} \rightarrow \mathrm{HOO} \bullet \\
& 2 \mathrm{HO} \rightarrow \mathrm{H}_{2} \mathrm{O}_{2} \\
& 2 \mathrm{HOO} \bullet \rightarrow \mathrm{H}_{2} \mathrm{O}_{2}+\mathrm{O}_{2}
\end{aligned}
$$

In the presence of cavitation $\mathrm{H}_{2} \mathrm{O}_{2}$ can dissociate to form $\mathrm{HO} \bullet$ radicals, however it can also produce less oxidative species in parallel: ${ }^{17}$

$$
\begin{aligned}
& \mathrm{H}_{2} \mathrm{O}_{2} \rightarrow \mathrm{HO} \bullet+\mathrm{HO} \bullet \\
& \mathrm{HO} \bullet+\mathrm{HO} \bullet \rightarrow \mathrm{H}_{2} \mathrm{O}_{2} \\
& \mathrm{H}_{2} \mathrm{O}_{2}+\mathrm{HO} \bullet \rightarrow \mathrm{HO}_{2} \bullet+\mathrm{H}_{2} \mathrm{O} \\
& \mathrm{HO}_{2}+\mathrm{HO}_{2} \bullet \rightarrow \mathrm{H}_{2} \mathrm{O}_{2}+\mathrm{O}_{2} \\
& \mathrm{HO} \bullet+\mathrm{O}_{2} \rightarrow \mathrm{HO}_{2} \bullet+\mathrm{O} \bullet
\end{aligned}
$$

Apart from the chemical effects, e.g. the formation of hydroxyl (HO•) and peroxyl (HOO•) radicals as well as hydrogen peroxide duo to the homolytic cleavage of water molecules, HC induces mechanical effects on bulk liquid in the form of severe turbulence, shear stresses, velocity and pressure pulsations, shock waves, evaporation and the condensation of the solution constituents etc. ${ }^{12,15} \mathrm{HC}$ can therefore be applied also to improve the mass transfer of the applied oxidants or as a hybrid (complementary) process, including disinfection. ${ }^{12,18-20}$

In this study, the effects of $\mathrm{HC}$ on $\mathrm{H}_{2} \mathrm{O}_{2} / \mathrm{UV}$ AOPs were investigated. $\mathrm{HC}$ was generated at the entry point to photolytic plug-flow reactor and the treatment performance was studied on the samples containing methylene blue (MB) dye (an industrial dye, but with a typical reactivity to $\mathrm{HO} \bullet$ and therefore highly suitable to assess and compare AOPs), humic acid (HA) as a source of DOC (representing NOM), and selected micropollutants: metaldehyde (common and widespread pesticide), diatrizoic acid and iohexol (X-ray contrast agents used in medical applications). ${ }^{1,21-24}$

\section{Experimental}

\section{1. Set-up}

The system is represented in Figure 1. Sample water from the tank was drawn via a frequency-controlled circulation pump with $0.75 \mathrm{~kW}$ installed power. System was equipped with power consumption meters that enabled the calculation of electrical energy per order of the pollutant removal $\left(E_{\mathrm{EO}}\right)$. Water flow, temperature and pressures (at the entry and the exit of UV reactor) were continuously 
measured with precise electronic instruments. The acquired data were stored in the computer for analyses. $\mathrm{H}_{2} \mathrm{O}_{2}$ (30\% w/w, Ph. Eur., USP by AppliChem, Darmstadt, Germany) was dosed into the system via a precise metering pump prior to the photolytic UV reactor, from where the water was returned to the tank. Water flow was maintained in the range of $0.20-0.25 \mathrm{~L} \mathrm{~s}^{-1}$, depending on the applied treatment configuration. photolytic reactor (as shown in Figure 2), with the arrangement of 6 concentric monochromatic UV lamps, each with power of $12.5 \mathrm{~W}$ at a wavelength of $254 \mathrm{~nm}$. The UV lamps were placed outside the quartz glass pipe with reflectors directing the photons towards the centre of the pipe and thus concentrating the UV irradiance in the zone with the highest axial velocity and distributing the UV fluence rate across the cross-section following turbulent

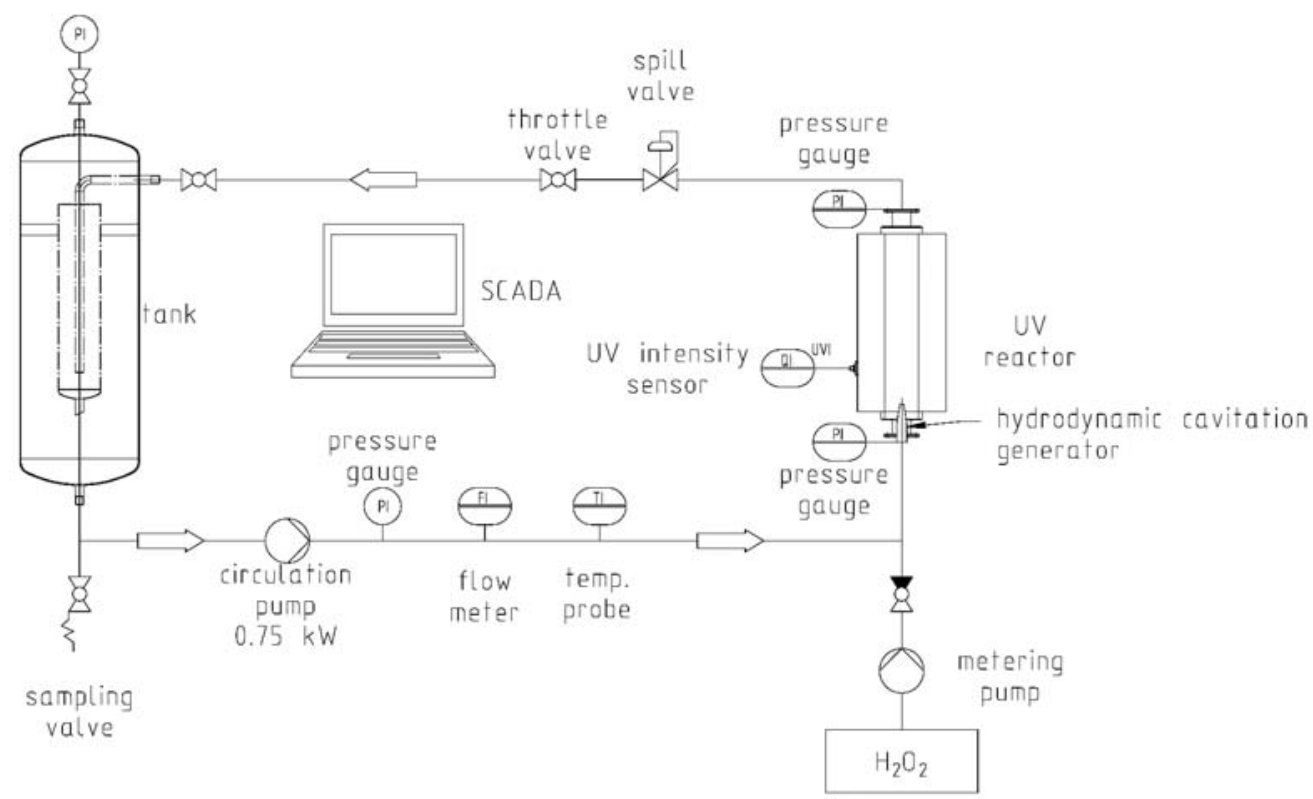

Figure 1. Design of the experimental set-up.

UV reactor (type E10-PH by Wedeco, Germany) consisted of an annular vertical quartz glass pipe (diameter $=61 \mathrm{~mm}$, length $=970 \mathrm{~mm}$ ), serving as a plug flow

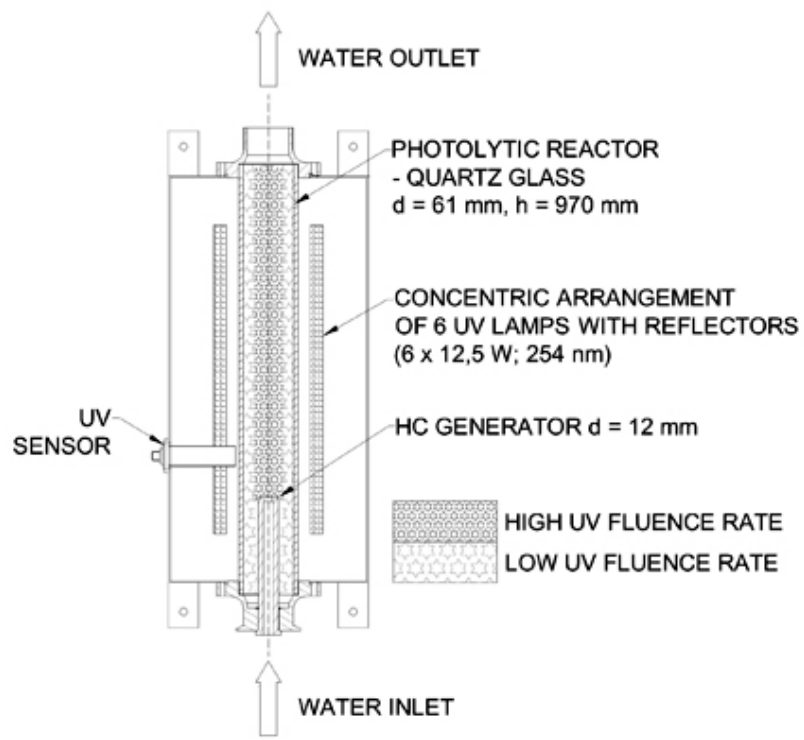

Figure 2. Photolytic UV reactor cross-section with HC generator (illustration). hydrodynamic flow pattern (as illustrated in Figure 2). The system was equipped with an UV irradiance sensor (type SO13599 by Wedeco, Germany; Resolution $0.1 \mathrm{~W}$ $\mathrm{m}^{-2}$; Accuracy $\pm 3 \%$ ), with $160^{\circ}$ opening angle. UV reactor enabled installation of $\mathrm{HC}$ generation elements at the entry to the reactor (Figure 1). All the experimental configurations, presented in Table 1 , were used as $\mathrm{H}_{2} \mathrm{O}_{2} / \mathrm{UV}$ AOPs alone and with the application of $\mathrm{HC}$.

\section{2. Calibration of Dose-performance of the UV System}

Methylene blue water solutions are relatively poorly decolorized by the UV light itself, but are very reactive with $\mathrm{HO} \bullet$ generated by, for example, $\mathrm{H}_{2} \mathrm{O}_{2} / \mathrm{UV}$ AOPs. ${ }^{23}$ Therefore, MB can be used as a benchmark test for $\mathrm{H}_{2} \mathrm{O}_{2} / \mathrm{UV}$ AOPs. ${ }^{23,25}$ In parallel, experiments were run in the $\mathrm{H}_{2} \mathrm{O}_{2} / \mathrm{UV}$ experimental set-up and on UV-collimated beam device (CBD, type 11-1 by Wedeco, Germany) in petri dishes, where accurate applied UV dosages can be established based on the exposure time of the sample and the known geometry of the petri dish and the UV fluence rate distribution. ${ }^{23}$ For a known UV dosage from CBD tests, MB degradation can be determined using the UVVIS spectroscopy by the reduction of light absorbance (at a wavelength of $610 \mathrm{~nm}$ in this research). Results of the CBD tests were compared to the absorbance reduction ob- 
tained in the experimental $\mathrm{H}_{2} \mathrm{O}_{2} / \mathrm{UV}$ set-up, thus enabling its dose-performance calibration.

\section{3. Hydrodynamic Cavitation}

One of the benefits of $\mathrm{HC}$ application is its scale-up possibility. ${ }^{12,13,15}$ Therefore, this potential was utilized and the experiments were performed using $83 \mathrm{~L}$ of the total volume for humic acid and micropollutant removal as well as $50 \mathrm{~L}$ for methylene blue removal. The intensity of cavitation phenomena is described by dimensionless cavitation number $\left(C_{v}\right)$ :

$$
C_{v}=\left(P_{2}-P_{v}\right) /\left(1 / 2 \cdot \rho \cdot v^{2}\right)
$$

where $P_{2}$ is absolute downstream pressure (backpressure) [Pa], $P_{v}$ is vapour pressure at a given temperature [Pa], $\rho$ is water density at a given temperature $\left[\mathrm{kg} \mathrm{m}^{-3}\right]$ and $v$ is flow velocity $\left[\mathrm{m} \mathrm{s}^{-1}\right]$ at the throat of the constriction. Another important parameter is the number of passes $(N O P)$ through the HC generator. ${ }^{26}$ Relatively low NOP was used in this research, namely up to 9 for humic acid and micropollutants removal and between 9 and 12 for methylene blue removal. From the previous research reported in the literature, ${ }^{15,26,27}$ several dozen to several hundreds of even thousands of passes are required to generate chemical effects that result in detectable amount of radical species to assure chemical oxidation by HC. For NOP in the range up to several dozen mechanical effects of $\mathrm{HC}$ would prevail and this has been the case in the present research. Simultaneously, NOP is also a characteristic of $\mathrm{H}_{2} \mathrm{O}_{2} / \mathrm{UV}$ AOPs without $\mathrm{HC}$, the figure representing the number of passes through the UV reactor (Table 1). Characteristically, experiments using $\mathrm{HC}$ involve external temperature management of the system (e.g. heat exchangers etc.). ${ }^{16,26,28}$ However, due to the relatively large bulk of the sample volumes (50-83 L), low NOP and short experiment duration, the system was not additionally cooled-down and the temperatures were kept in the range of 23-27 ${ }^{\circ} \mathrm{C}$ for all of the applied configurations.

Various geometry of HC generators was also tested (nozzle with single opening and orifice plates with 4, 8 and 18 openings, Figure 3 and Table 2) in relation to the treatment performance of methylene blue decolourization. For the experiments with humic acid and micropollutants only an orifice plate with 8 openings $(n=8)$ was used for $\mathrm{H}_{2} \mathrm{O}_{2}$ /UV AOPs coupled with $\mathrm{HC}$.
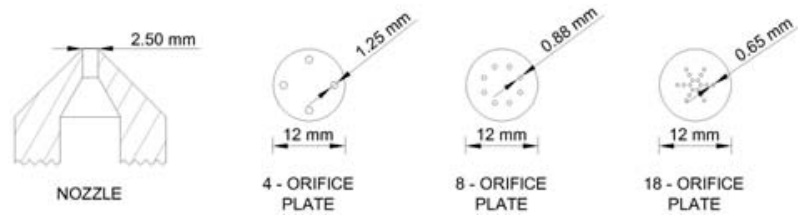

Figure 3: Geometry of the applied HC generators.

\section{4. Sample Preparation}

Experiments were performed using samples of tap water to which prepared solutions of selected pollutants were added. Tap water was supplied from deep wells with practically no turbidity $(<0.06 \mathrm{NTU})$, no iron and manganese (both $\left.<0.01 \mathrm{mg} \mathrm{L}^{-1}\right)$, practically no colour $(<$ $\left.0.001 \mathrm{~cm}^{-1}\right)$ and low DOC $\left(<1.0 \mathrm{mg} \mathrm{L}^{-1}\right)$; however with relatively high concentration of carbonate species (total hardness $=3.0-3.3 \mathrm{mmol} \mathrm{L}^{-1}$ as $\mathrm{CaCO}_{3}$ ) as the potential $\mathrm{HO} \cdot$ scavengers (analyses from tap water supplier Stadtwerke Herford GmbH, Herford, Germany; obtained

Table 1. Characteristics of the experimental conditions.

\begin{tabular}{|c|c|c|c|c|c|}
\hline$\overline{\text { Pollutant }}$ & $\begin{array}{c}\text { Parameter for } \\
\text { evaluation of removal } \\
\text { efficiency }\end{array}$ & $\begin{array}{c}\text { Parameter value } \\
\text { at thestart of the } \\
\text { experiment }\end{array}$ & $\begin{array}{c}\text { Applied } \mathrm{H}_{2} \mathrm{O}_{2} \\
\text { dosage } \\
{\left[\mathrm{mg} \mathrm{L}^{-1}\right]}\end{array}$ & $\begin{array}{c}\text { Applied UV } \\
\text { dosage } \\
{\left[\mathrm{mJ} \mathrm{cm} \mathbf{c m}^{-2}\right]}\end{array}$ & $\begin{array}{c}\mathrm{NOP} \\
{[/]}\end{array}$ \\
\hline Methylene blue & $\begin{array}{c}\text { Absorbance at } \lambda=610 \mathrm{~nm} \\
{\left[\mathrm{~cm}^{-1}\right]}\end{array}$ & $0.358-0.375$ & $\begin{array}{c}5.0 \\
10.0\end{array}$ & $\begin{array}{l}500-2800 \\
500-1900\end{array}$ & $\begin{array}{r}12 \\
9\end{array}$ \\
\hline Humic acid & $\mathrm{DOC}\left[\mathrm{mg} \mathrm{L}^{-1}\right]$ & $1.1-3.4$ & $4.0-12.0$ & $300-1800$ & 9 \\
\hline $\begin{array}{l}\text { Micropollutants } \\
\text { (metaldehyde, diatrizoic } \\
\text { acid, iohexol) }\end{array}$ & $\begin{array}{c}\text { Concentration } \\
{\left[\mu \mathrm{g} \mathrm{L}^{-1}\right]}\end{array}$ & $8.2-11.0$ & 10.0 & $450-2700$ & 9 \\
\hline
\end{tabular}

Table 2. Features of the applied HC generators.

\begin{tabular}{|c|c|c|c|c|c|c|}
\hline $\begin{array}{l}\text { HC generator } \\
\text { type }\end{array}$ & $\begin{array}{c}\text { Number of } \\
\text { openings } \\
n[/]\end{array}$ & $\begin{array}{c}\text { Opening } \\
\text { diameter } \\
{[\mathrm{mm}]}\end{array}$ & $\begin{array}{c}\text { Total } \\
\text { cross-section } \\
{\left[\mathbf{m m}^{2}\right]}\end{array}$ & $\begin{array}{c}\text { Average calculated } \\
\text { water velocity } \\
\text { at constriction }[\mathrm{m} / \mathrm{s}]\end{array}$ & $C_{v}[/]$ & $\begin{array}{c}\text { Power consumption } \\
\text { of the circulation } \\
\text { pump }[\mathbf{k W}]\end{array}$ \\
\hline Nozzle & 1 & 2.50 & 4.9 & 40.7 & $0.17-0.23$ & 0.75 \\
\hline Orifice plate & 4 & 1.25 & 4.9 & 40.7 & $0.16-0.20$ & 0.73 \\
\hline Orifice plate & 8 & 0.90 & 4.9 & 41.1 & $0.14-0.18$ & 0.68 \\
\hline Orifice plate & 18 & 0.65 & 6.0 & 41.5 & $0.12-0.22$ & 0.55 \\
\hline
\end{tabular}


23.11.2013). $\mathrm{pH}$ of the solutions was not modified throughout the experiments and was ranging from 7.7 to 7.8 .

MB solution for each experiment was prepared by dissolving $0.200-0.210 \mathrm{~g}$ of MB hydrate as provided (by Sigma-Aldrich) in $500 \mathrm{~mL}$ of demineralized water and added to $50 \mathrm{~L}$ of the sample. This resulted in the initial light absorbance of the sample ranging between $0.358-0.375$ $\mathrm{cm}^{-1}$ at $\lambda=610 \mathrm{~nm}$. $\mathrm{UVA}_{254}$ was in the range $0.168 \pm$ $0.015 \mathrm{~cm}^{-1}$ (the UV light transmission at $\lambda=254 \mathrm{~m}$ of approx. $68 \%$ per $1 \mathrm{~cm}$ ) at the beginning of the experiments.

The solution of humic acid (HA, technical grade, Sigma-Aldrich, CAS: 1415-93-6) was prepared by dissolving $\mathrm{HA}$ in demineralized water in volumetric flasks. Mixture was kept in the dark at $20 \pm 1{ }^{\circ} \mathrm{C}$ for $48 \mathrm{~h}$ and mixed completely every $12 \mathrm{~h}$ prior to the filtration on laboratory filters (Whatman Ashless Grade 589/3, pore size 2 $\mu \mathrm{m})$ to remove suspended particles. HA solution was then added to the water sample used in the experimental set-up with $83 \mathrm{~L}$ of total volume and DOC concentrations ranging from 1 to $3 \mathrm{mg} \mathrm{L}^{-1}$. $\mathrm{UVA}_{254}$ was $0.067 \pm 0.02 \mathrm{~cm}^{-1}$ (the UV light transmission at $\lambda=254 \mathrm{~m}$ of approx. $86 \%$ per $1 \mathrm{~cm})$ at the beginning of the experiments.

The stock solution of the micropollutants was prepared from the reagents as provided, all analytical standard grade: (i) Metaldehyde (by Fluka - Sigma-Aldrich, CAS: 9002-91-9); (ii) Diatrizoic acid (by Sigma-Aldrich, CAS: 117-96-4); (iii) Iohexol (by Sigma-Aldrich, CAS: 6610895-0). After the preparation, the stock solution was kept in the dark at $4 \pm 1{ }^{\circ} \mathrm{C} .90 \mathrm{~mL}$ of the stock solution was added to each of the investigated samples in the experiments using $83 \mathrm{~L}$ of tap water, resulting in starting concentrations of the respective micropollutants between 8.2 and $11.0 \mu \mathrm{g} \mathrm{L}^{-1}$. $\mathrm{UVA}_{254}$ was, compared to MB and HA experiments, relatively very low in the range of $0.017 \pm 0.02$ $\mathrm{cm}^{-1}$.

\section{5. Analytical Methods}

UV-VIS spectrometry was performed on a laboratory spectrophotometer (type HACH DR5000, Germany) in $10 \mathrm{~mm}$ quartz cuvette with the calibration performed using deionised water (Water for chromatography, LC-MS Grade, LiChrosolv by Merck Millipore). For MB experiments and to detect the colour removal, an absorbance wavelength of $\lambda=610 \mathrm{~nm}\left(\mathrm{~A}_{610}\right)$ was used. For all the experiments the UV absorbance was measured at a wavelength of $\lambda=254 \mathrm{~nm}\left(\mathrm{UVA}_{254}\right)$. Hydrogen peroxide was determined using a titanium (IV) oxysulfate spectrophotometric method at a wavelength $\lambda=400$ $\mathrm{nm}$. DOC concentrations $\left[\mathrm{mg} \mathrm{L}^{-1}\right]$ were determined according to DIN EN 1484 standard, using Shimadzu TOC 5050 analyser.

Analyses of metaldehyde were performed on GC-MS after pre-concentration by solid-phase extraction. GC-MS system consisted of a gas chromatograph 6890 and a mass selective detector MSD 5973, both from Agilent Technologies (Waldbronn, Germany). Chromatographic separation was done on the Rxi-5ms column (by Restek $\mathrm{GmbH}$, Bad Homburg, Germany). $500 \mathrm{~mL}$ of water sample were pre-concentrated on $100 \mathrm{mg}$ of a polymeric material (Strata X, Phenomenex). Elution was done with 4 $\mathrm{mL}$ of dichloromethane which was then evaporated in a gentle stream of nitrogen to a final volume of $500 \mu \mathrm{L}$, and then an aliquot of $10 \mu \mathrm{L}$ was injected into a GC-MS system. Chromatographic separation was done on Restek Rxi-5 MS column $(30 \mathrm{~m} \times 0.25 \mathrm{~mm} \times 0.25 \mu \mathrm{m})$. Oven temperature started at $45^{\circ} \mathrm{C}$ which was held for 2 minutes and then raised to $160{ }^{\circ} \mathrm{C}$ at a rate of $10{ }^{\circ} \mathrm{C} \mathrm{min}{ }^{-1}$. After 3 min at $160^{\circ} \mathrm{C}$, the temperature was raised to $280{ }^{\circ} \mathrm{C}$ at a rate of $20^{\circ} \mathrm{C} \min ^{-1}$ and again held for 5 minutes. The quantification was done against the calibration in MilliQ water. Due to the relatively high concentrations used for the experiments, samples were diluted 1:10 prior to the extraction and thus the levels of quantification (LOQ) for metaldehyde were $0.5 \mu \mathrm{g} \mathrm{L}{ }^{-1}$.

The analyses of diatrizoic acid and iohexol were performed on HPLC-MS-MS after the pre-concentration by the solid-phase extraction. HPLC-MS-MS system which consisted of a liquid chromatograph 1290 Infinity from Agilent Technologies (Waldbronn, Germany) coupled via an electrospray interface to an API 5500 tandem mass spectrometer (AB Sciex, Langen, Germany). The chromatographic separation was done on a Thermo Fisher Hypersil Gold column $(100 \mathrm{~mm} \times 2.1 \mathrm{~mm}, 3 \mu \mathrm{m}$ particle size). $200 \mathrm{~mL}$ of water sample were adjusted to a $\mathrm{pH}$ of 3 and pre-concentrated on $200 \mathrm{mg}$ of a styrene-divinylbenzene copolymer (SDB1, Fisher Scientific). Elution was done with $5 \mathrm{~mL}$ of methanol and subsequently with $5 \mathrm{~mL}$ of acetonitrile. The elution solvents were evaporated to dryness and the dry residue reconstituted with $500 \mu \mathrm{L}$ of HPLC grade water. Then an aliquot of $100 \mu \mathrm{L}$ was injected into a HPLC-MS-MS system. Chromatographic separation was performed by using an aqueous solution of 5 $\mathrm{mM}$ ammonium formate and $0.1 \%$ formic acid (eluent $\mathrm{A}$ ), and a solution of $5 \mathrm{mM}$ ammonium formate and $0.1 \%$ formic acid in methanol (eluent B) as the elution solvents. The elution gradient started at $95 \%$ of eluent A, gradually changed to $15 \%$ of eluent $\mathrm{B}$ in first 7 minutes, and to $100 \%$ of eluent B up to $13 \mathrm{~min}$, then stayed constant for 6 min, and finally adjusted back to $95 \%$ of eluent A between $\min 19$ and $\min 20$. Flow rate of the eluent was $0.25 \mathrm{~mL}$ $\mathrm{min}^{-1}$ and the temperature of the column oven was set to $40{ }^{\circ} \mathrm{C}$. The detection of both target compounds was done in positive mode applying an ionisation voltage of $5.5 \mathrm{kV}$. Before and after each series of samples, a control sample and a blank sample were run. Quantification was done against the calibration in MilliQ water. Due to the relatively high concentrations used for the experiments, samples were diluted 1:10 prior to the extraction and thus LOQ were $0.1 \mu \mathrm{g} \mathrm{L}^{-1}$ for each of the X-ray contrast agents. 


\section{6. Removal of the Selected Organic Pollutants}

A decrease in the concentrations of the organic pollutants used herein was described through pseudo-first order kinetic equation:

$$
\ln \left(\left[x_{t}\right] /\left[x_{0}\right]\right)=-k \cdot t
$$

where $x_{0}$ is the initial value of the evaluated parameter $\left(\mathrm{A}_{610}\left[\mathrm{~cm}^{-1}\right]\right.$, DOC $\left[\mathrm{mg} \mathrm{L}^{-1}\right]$, micropollutants concentration $\left[\mu \mathrm{g} \mathrm{L}^{-1}\right]$; Table 1$), x_{t}$ the value of the same evaluated parameter at experiment time $t[\mathrm{~min}]$ and $k\left[\mathrm{~min}^{-1}\right]$ the pseudo-first order rate constant. To express the degree of correlation between the removal rate and the applied UV dosages and due to the fact that linear regression could be applied (in logarithmic scale), determination coefficients $\left(R^{2}\right)$ were calculated for each individual pollutant.

\section{Results and Discussion}

\section{1. Decolourization of Methylene Blue Solution}

As presented in Table 3 and Figures 4-5, the applied $\mathrm{H}_{2} \mathrm{O}_{2} / \mathrm{UV}$ AOPs resulted in $40 \%$ discoloration of the $\mathrm{MB}$ solution at a wavelength of $\lambda=610 \mathrm{~nm}$ at $\mathrm{H}_{2} \mathrm{O}_{2}$ dosage of $5 \mathrm{mg} \mathrm{L}^{-1}$ and the UV dosage of $2800 \mathrm{~mJ} \mathrm{~cm}^{-2}$ and $60 \%$ discoloration of the $\mathrm{MB}$ solution at a wavelength of $\lambda=$ $610 \mathrm{~nm}$ at $\mathrm{H}_{2} \mathrm{O}_{2}$ dosage of $10 \mathrm{mg} \mathrm{L}^{-1}$ and the UV dosage of $1900 \mathrm{~mJ} \mathrm{~cm}{ }^{-2}$. In both cases, the overall decolourization of MB was enhanced by the application of HC by up to approx. $15 \%$ under the conditions described herein. The results of HC coupled with AOPs are expressed as an average of all the applied HC experiment configurations (Table 2). From the results obtained, the application of $\mathrm{HC}$ obviously improved mass transfer of $\mathrm{H}_{2} \mathrm{O}_{2}$ and its exposure to UV irradiation, based on changes in hydrodynamic characteristic in the UV reactor and due to the mechanisms induced by the $\mathrm{HC}$ which consequently yielded more $\mathrm{HO}$ and hence improved $\mathrm{MB}$ decolourization.

$\mathrm{UVA}_{254}$ remained unchanged $\left(0.168 \pm 0.015 \mathrm{~cm}^{-1}\right)$ throughout the treatment with $5 \mathrm{mg} \mathrm{L}^{-1}$ of $\mathrm{H}_{2} \mathrm{O}_{2}$, independent of UV dosage. On the contrary, $\mathrm{UVA}_{254}$ was reduced by $20-24 \%$ throughout the treatment with $10 \mathrm{mg} \mathrm{L}^{-1}$ of $\mathrm{H}_{2} \mathrm{O}_{2}$ and UV dosage of $1900 \mathrm{~mJ} \mathrm{~cm}^{-2}$. This reduction was

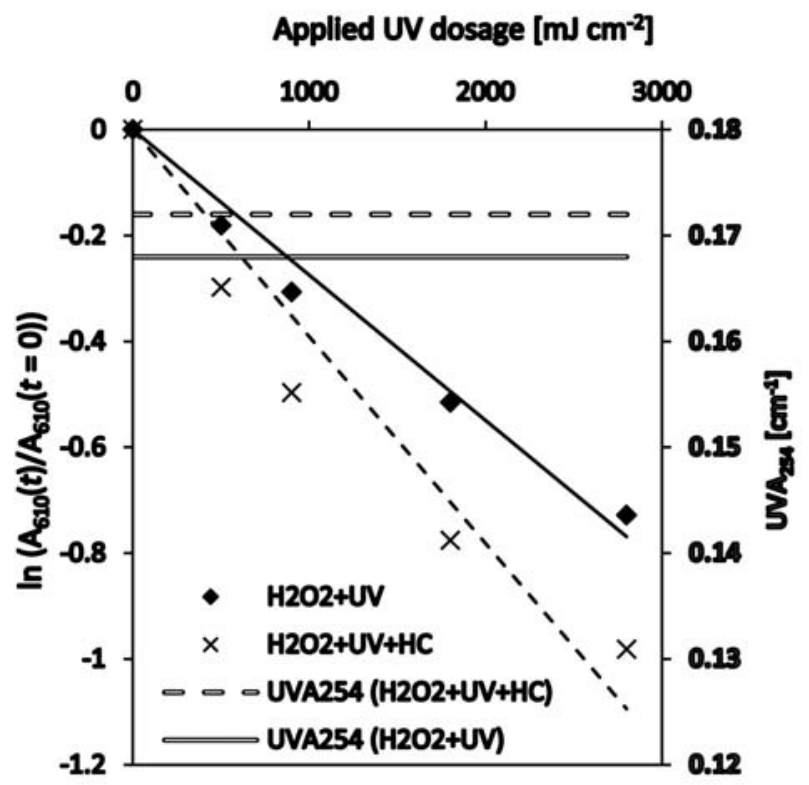

Figure 4. Decolourization of the MB solution as a function of applied UV dosage; $\mathrm{H}_{2} \mathrm{O}_{2}$ dosage $5 \mathrm{mg} \mathrm{L}^{-1}$.

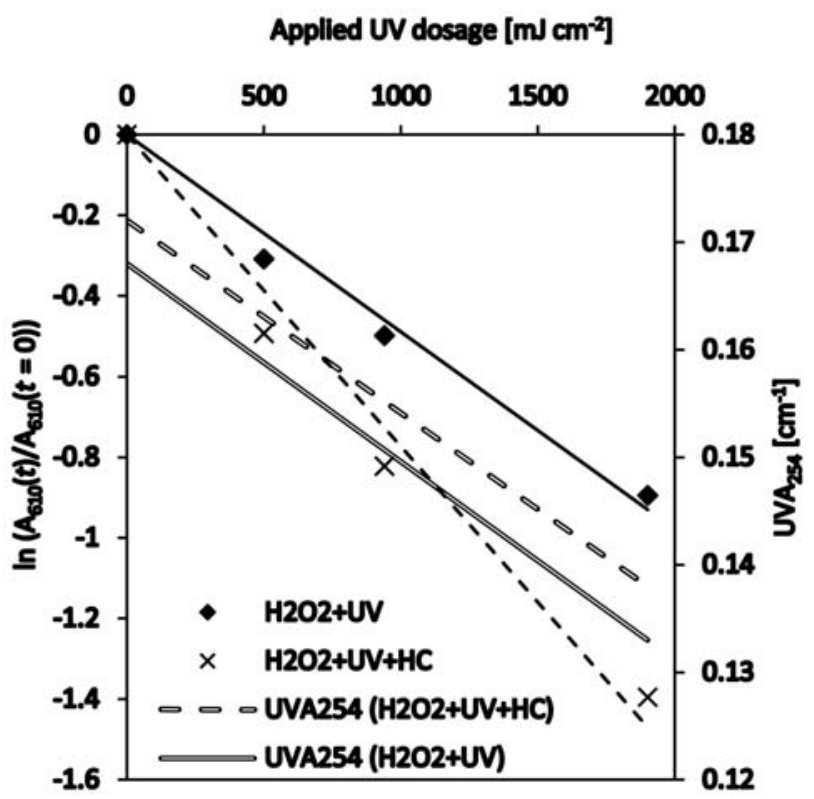

Figure 5. Decolourization of the MB solution as a function of applied UV dosage; $\mathrm{H}_{2} \mathrm{O}_{2}$ dosage $10 \mathrm{mg} \mathrm{L}^{-1}$.

Table 3. Kinetic parameters and efficiency of MB solution decolourization.

\begin{tabular}{|c|c|c|c|c|c|c|c|}
\hline $\begin{array}{l}\text { Experimental } \\
\text { configuration }\end{array}$ & $\begin{array}{c}\text { Applied } \\
\mathrm{H}_{2} \mathrm{O}_{2} \text { dosage } \\
{\left[\mathrm{mg} \mathrm{L}^{-1}\right]}\end{array}$ & 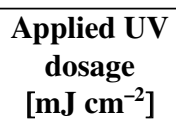 & $\begin{array}{c}k \\
{\left[10^{-4}, \mathrm{~min}^{-1}\right]}\end{array}$ & $\begin{array}{l}R^{2} \\
{[/]}\end{array}$ & $\begin{array}{c}\text { Average } \mathbf{A}_{610} \\
\text { decolourization } \\
\text { efficiency }[\%]\end{array}$ & $\begin{array}{c}\mathrm{UVA}_{254}\left[\mathrm{~cm}^{-1}\right] \\
\text { before the } \\
\text { treatment }\end{array}$ & $\begin{array}{c}\mathrm{UVA}_{254}\left[\mathrm{~cm}^{-1}\right] \\
\text { after the } \\
\text { treatment }\end{array}$ \\
\hline$\overline{\mathrm{H}_{2} \mathrm{O}_{2}+\mathrm{UV}}$ & 5 & 2800 & 2.75 & 0.98 & 40.3 & $0.168 \pm 0.015$ & $0.168 \pm 0.015$ \\
\hline $\mathrm{H}_{2} \mathrm{O}_{2}+\mathrm{UV}+\mathrm{HC}$ & 5 & 2800 & 3.91 & 0.92 & 53.4 & $0.172 \pm 0.015$ & $0.172 \pm 0.015$ \\
\hline $\mathrm{H}_{2} \mathrm{O}_{2}+\mathrm{UV}$ & 10 & 1900 & 4.89 & 0.98 & 59.1 & $0.168 \pm 0.015$ & $0.133 \pm 0.013$ \\
\hline $\mathrm{H}_{2} \mathrm{O}_{2}+\mathrm{UV}+\mathrm{HC}$ & 10 & 1900 & 7.74 & 0.97 & 74.8 & $0.172 \pm 0.015$ & $0.138 \pm 0.010$ \\
\hline
\end{tabular}


evident in the same range for $\mathrm{H}_{2} \mathrm{O}_{2} / \mathrm{UV}$ AOPs alone or coupled with HC. Therefore, the treatment predominately resulted in decolourization at $\lambda=610 \mathrm{~nm}$, i.e. the decomposition of MB molecules, however, the oxidation products have obviously remained as chromophores (aromatic or molecules with multiple chemical bond) that absorb UV light. ${ }^{1}$ To increase $\mathrm{UVA}_{254}$ reduction, higher dosages of $\mathrm{H}_{2} \mathrm{O}_{2}$ should be applied.

\section{2. Influence of HC Generator Geometry on MB Solution Decolourization Efficiency}

According to the results of already conducted research on HC, geometry of the generator or constriction (e.g. orifice plates, Venturi, rotation blades etc.) can significantly change the performance of the treatment. ${ }^{13,26,29}$ Predictions or model forecasts and evaluations on the subject are for now virtually impossible due to numerous influencing parameters and their variations that still have not been researched to the extent allowing for generalisation. ${ }^{27,30}$ Besides the geometry of the $\mathrm{HC}$ generators (e.g. hydraulic radii, the number and the distribution of openings of the orifice plates, converging and diverging angles of Venturi injectors etc.), the influence of the inlet and recovered pressures of $\mathrm{HC}$, presence and concentrations of dissolved gasses and process intensifying chemical agents etc., are among the variables that affect the process. ${ }^{26}$

The kinetics of MB discolouration using different HC generators are presented in Figures 6 and 7. The differences in the MB decolourization were not found to be significant $( \pm 5-10 \%$ between different applied HC generator geometries), however, the power consumption of the circulation pump to produce $C_{v}$ in the same range could differ by as much as $40 \%$ between them (Table 2), with the 18-opening orifice plate $(\mathrm{n}=18)$ consuming the least and the nozzle $(n=1)$ the most energy. Of the HC generators tested, the nozzle also resulted in lower MB decolourization than the other geometries (Figures 6 and 7), especially at $\mathrm{H}_{2} \mathrm{O}_{2}$ dosage of $10 \mathrm{mg} \mathrm{L}^{-1}$, while orifice plates with $n=4$ and 8 were performing better (both in the same order of magnitude) and the orifice plate with $n=18$ in the range between the other types. Depending on the observations made, the results of other research ${ }^{13,26}$ can be supported and we could not generally and conclusively declare the best performing $\mathrm{HC}$ generator geometry, although from the MB decolourization results and electrical energy consumption, orifice plate with 8 openings was found to be optimum following the conditions of the experiment. Derived for the results obtained herein, the evaluations of the most optimal HC generator type and the geometry intended for a hybrid AOP are suggested for each experimental set-up configuration, type and concentration of the pollutants, characteristics of the water matrix and the dosages of the simultaneously applied oxidants (e.g. $\mathrm{H}_{2} \mathrm{O}_{2}$, $\mathrm{UV}, \mathrm{O}_{3}$ etc.).

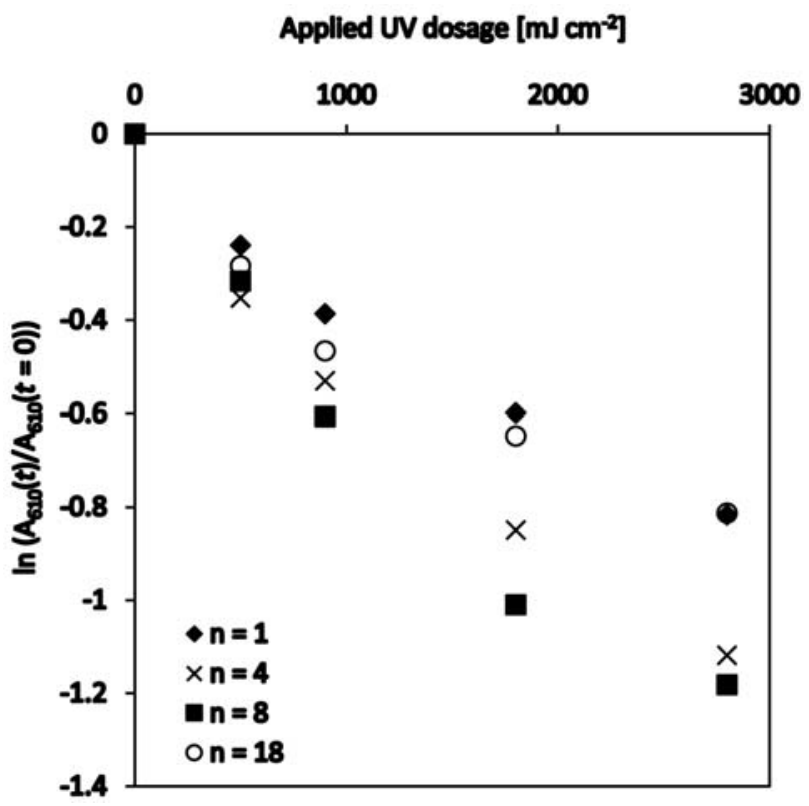

Figure 6. MB decolourization using different $\mathrm{HC}$ generator geometry ( $n$ represents the number of openings of the $\mathrm{HC}$ generator, as described in Figure 3 and Table 2); $\mathrm{H}_{2} \mathrm{O}_{2}$ dosage $5 \mathrm{mg} \mathrm{L}^{-1}$.

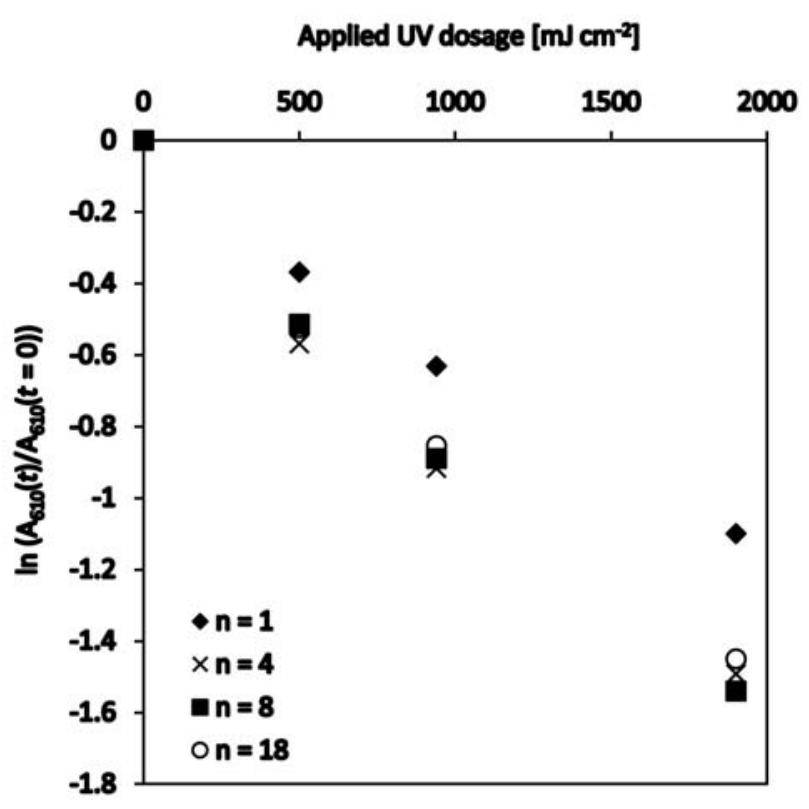

Figure 7. MB decolourization using different $\mathrm{HC}$ generator geometry ( $n$ represents the number of openings of the $\mathrm{HC}$ generator, as described in Figure 3 and Table 2); $\mathrm{H}_{2} \mathrm{O}_{2}$ dosage $10 \mathrm{mg} \mathrm{L}^{-1}$.

\section{3. DOC Removal from Humic Acid Solution}

As presented in Figure 8, DOC oxidation in this experiment was apparently a two-stage reaction - initially, at relatively low $\mathrm{UV}$ and $\mathrm{H}_{2} \mathrm{O}_{2}$ dosages up to 300 $\mathrm{mJ} \mathrm{cm}{ }^{-2}$ and $4 \mathrm{mg} \mathrm{L}^{-1}$, respectively, the removal rate was 
significantly higher than at the increased dosages of the applied oxidants. The first stage represents conditions of the relatively high DOC concentrations and the relatively high $\mathrm{UVA}_{254}$ values at the start of the experiments (Table 4). The second stage represents the conditions of the relatively lower DOC concentrations and lower $\mathrm{UVA}_{254} . \mathrm{H}_{2} \mathrm{O}_{2} / \mathrm{UV}$ AOPs alone were able to reduce approx. $15-23 \%$ of DOC under herein described conditions, whereas coupling the processes with $\mathrm{HC}$ resulted in approx. 30-50\% better DOC reduction, comparatively (Table 4). Apparently, the application of $\mathrm{HC}$ resulted in improved DOC removal, especially in the first stage, which again leads to the understanding of advantages of such hybrid $\mathrm{H}_{2} \mathrm{O}_{2} / \mathrm{UV}$ AOPs. Moreover, due to relatively high $\mathrm{UVA}_{254}$ in the first stage, the benefits of HC application are emphasized in less favourable conditions for UV photolysis. Related to $\mathrm{UVA}_{254}$, both experiment configurations gave a comparable range of reduction, eventually approx. $45 \%$ at the highest dosages of the applied oxidants (Table 4).

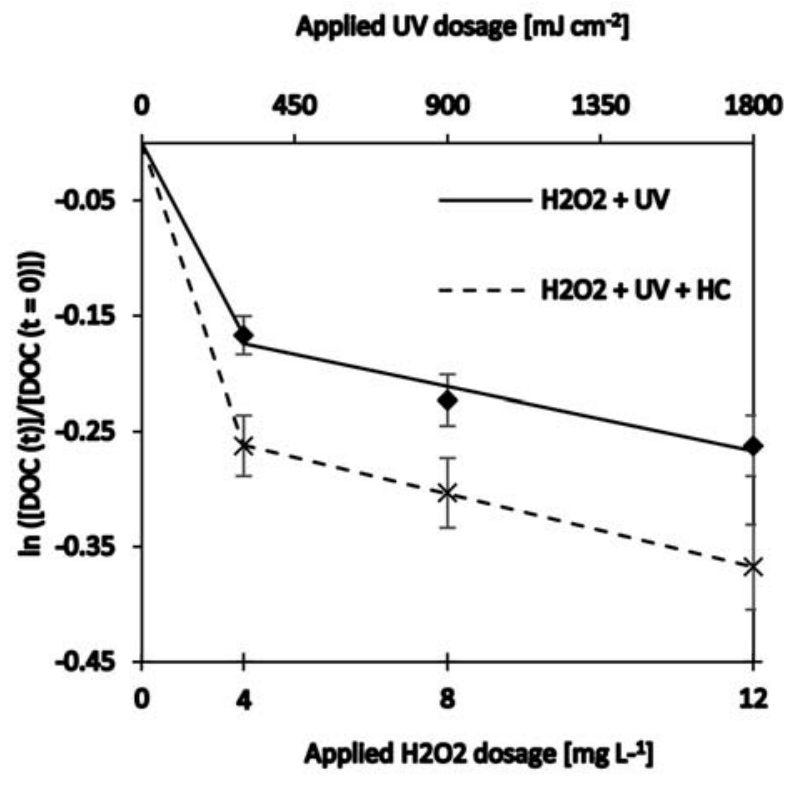

Figure 5. Decolourization of the MB solution as a function of applied UV dosage; $\mathrm{H}_{2} \mathrm{O}_{2}$ dosage $10 \mathrm{mg} \mathrm{L}^{-1}$.

\section{4. Removal of Micropollutants}

These sets of experiments were performed by the application of $10 \mathrm{mg} \mathrm{L}^{-1}$ of $\mathrm{H}_{2} \mathrm{O}_{2}$ and only UV dosages were varied between 450 and $2700 \mathrm{~mJ} \mathrm{~cm}^{-2}$. Contrary to the experiments with MB and HA, water matrix used herein (described in Section 2.4), had only a very low $\mathrm{UVA}_{254}$, namely $0.017 \pm 0.02 \mathrm{~cm}^{-1}$. Diatrizoic acid and iohexol (referred to as contrast agents) are both relatively highly susceptible to treatment by the UV irradiation and $\mathrm{H}_{2} \mathrm{O}_{2} / \mathrm{UV}$ AOPs. ${ }^{23}$ The required UV dosages for achieving the same degree of removal in the performed experiments were approx. 4-4.5 fold lower than the ones for the treatment of metaldehyde, which is much more recalcitrant, as presented in Figure 9. Moreover, the investigated contrast agents show roughly the same removal rates during the herein described conditions, therefore the representation in Figure 9 relates to both. Since the LOQs possible by the analytical methods used $\left(0.5 \mu \mathrm{g} \mathrm{L}{ }^{-1}\right.$ for metaldehyde and $0.1 \mu \mathrm{g} \mathrm{L}{ }^{-1}$ for the contrast agents) were reached by applying the relatively low UV dosages in the case of the contrast agents, their removal was only observed in the range up to $450 \mathrm{~mJ} \mathrm{~cm}^{-2}$, where already $90-95 \%$ removal had been reached. The removal of metaldehyde of the same order of magnitude was only reached applying the UV dosages in the range of $2000-2700 \mathrm{~mJ} \mathrm{~cm}^{-2}$.

The application of $\mathrm{HC}$ was not found to improve the removal of the contrast agents under the conditions described herein or was even lowering the removal rate by approx. $5 \%$. In the case of metaldehyde that is much more persistent, $\mathrm{HC}$ was able to improve the removal rate by approx. $10 \%$ at the UV dosages above $1350 \mathrm{~mJ} \mathrm{~cm}^{-2}$. Nevertheless, taking into account the uncertainties related to the methods applied, distinct benefits of $\mathrm{HC}$ applications were not as obvious as in the case of MB or HA removal (Sections 3.1.1 and 3.1.3). Here the pollutants' concentrations were higher by about 3 orders of magnitude and the $\mathrm{UVA}_{254}$ was comparatively much higher, with the latter representing much less favourable conditions for photolysis based $\mathrm{H}_{2} \mathrm{O}_{2} / \mathrm{UV}$ AOPs. In the case of the micropollutants removal, water matrix was of much lesser $\mathrm{UVA}_{254}$, and the ratios of the dosages of applied oxidants over the quantity of the pollutants were approx. 3 orders of magnitude higher than in the case of MB and HA experiments. Altogether, these conditions did not emphasize the potential be-

Table 4. Efficiency of DOC removal and $\mathrm{UVA}_{254}$ reduction.

\begin{tabular}{|c|c|c|c|c|c|c|}
\hline $\begin{array}{l}\text { Experimental } \\
\text { configuration }\end{array}$ & $\begin{array}{c}\text { Applied } \mathrm{H}_{2} \mathrm{O}_{2} \\
\text { dosage } \\
{\left[\mathrm{mg} \mathrm{L}^{-1}\right]}\end{array}$ & $\begin{array}{c}\text { Applied UV } \\
\text { dosage } \\
{\left[\mathrm{mJ} \mathrm{cm} \mathbf{~ c m}^{-2}\right]}\end{array}$ & $\begin{array}{c}\text { Average DOC } \\
\text { removal } \\
\text { efficiency [\%] }\end{array}$ & $\begin{array}{c}\text { UVA }_{254} \text { before } \\
\text { the treatment } \\
{\left[\mathrm{cm}^{-1}\right]}\end{array}$ & $\begin{array}{c}\mathrm{UVA}_{254} \text { after } \\
\text { the treatment } \\
{\left[\mathrm{cm}^{-1}\right]}\end{array}$ & $\begin{array}{c}\text { Average UVA } \mathrm{UVA}_{254} \\
\text { reduction } \\
\text { [\%] configuration }\end{array}$ \\
\hline$\overline{\mathrm{H}_{2} \mathrm{O}_{2}+\mathrm{UV}}$ & 4 & 300 & 15.4 & $0.066 \pm 0.003$ & $0.062 \pm 0.002$ & 5.4 \\
\hline $\mathrm{H}_{2} \mathrm{O}_{2}+\mathrm{UV}+\mathrm{HC}$ & 4 & 300 & 23.1 & $0.068 \pm 0.003$ & $0.063 \pm 0.002$ & 7.4 \\
\hline $\mathrm{H}_{2} \mathrm{O}_{2}+\mathrm{UV}$ & 8 & 900 & 20.0 & $0.062 \pm 0.002$ & $0.050 \pm 0.002$ & 24.3 \\
\hline $\mathrm{H}_{2} \mathrm{O}_{2}+\mathrm{UV}+\mathrm{HC}$ & 8 & 900 & 26.2 & $0.063 \pm 0.002$ & $0.051 \pm 0.002$ & 24.3 \\
\hline $\mathrm{H}_{2} \mathrm{O}_{2}+\mathrm{UV}$ & 12 & 1800 & 23.1 & $0.050 \pm 0.002$ & $0.036 \pm 0.002$ & 44.9 \\
\hline $\mathrm{H}_{2} \mathrm{O}_{2}+\mathrm{UV}+\mathrm{HC}$ & 12 & 1800 & 30.8 & $0.051 \pm 0.002$ & $0.037 \pm 0.002$ & 45.3 \\
\hline
\end{tabular}


nefits of $\mathrm{HC}$ effects that were much more obvious for the other experiments described herein.

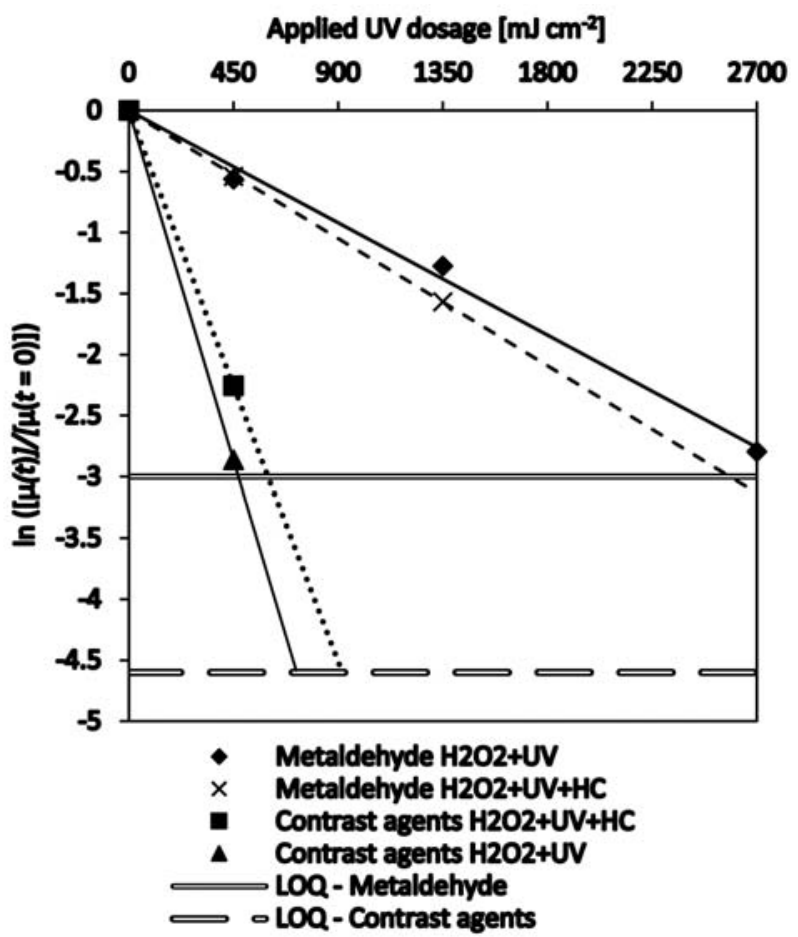

Figure 9. Micropollutants removal as a function of applied UV dosage; $\mathrm{H}_{2} \mathrm{O}_{2}$ dosage $10 \mathrm{mg} \mathrm{L}^{-1}$; $[\mu]$ represents concentration of respective micropollutant.

\section{5. Influence of $\mathrm{HC}$ on Hydrodynamic and Photolytic Conditions Inside the UV Reactor}

Much effort is put into the design of the efficient fluence rate distribution in the photolytic UV reactors, where the optimal distribution of UV lamps and flow pattern play a major role. ${ }^{31}$ The latter issue is commonly addressed applying various flow diverters, baffle plates or similar flow conditions optimizers. Potentially, the application of $\mathrm{HC}$ can be considered among the measures of addressing these challenges, as shown herein.

When operated without the $\mathrm{HC}$, the flow pattern through the UV photolytic reactor used herein was subjected to typical plug-flow conditions and turbulent velocity profile, as presented in Figure 10 a.). Reynolds number was calculated using the term:

$$
\operatorname{Re}=v \cdot d / v
$$

where $v\left[\mathrm{~m} \mathrm{~s}^{-1}\right]$ is the mean flow velocity in the cross-section of the pipe with the diameter $d[\mathrm{~m}]$ and in which case $v\left[\mathrm{~m}^{2} \mathrm{~s}^{-1}\right]$ is the kinematic viscosity of the water (approx. $10^{-6} \mathrm{~m}^{2} \mathrm{~s}^{-1}$ at $\left.20{ }^{\circ} \mathrm{C}\right) .^{32}$ The mean velocity of the water flow was quasi-constant in the range of $0.68-0.72 \mathrm{~m} \mathrm{~s}^{-1}$ and $R e$ in the range of 4200-5200. Based on the theoreti- cal grounds, the mean flow velocity in the cross-section ranges between $0.80-0.87$ of the maximum flow velocity in the centre of the pipe, which causes turbulent eddies near the pipe walls. ${ }^{32}$ These eddies are dissipated in the flow as it passes along the axis of the reactor and result only in relatively low radial and counter-current turbulence. Therefore, in the Sections 1, 2 and 3 of the UV reactor (Figure 10 a.), along its longitudinal axis, the flow conditions can be considered equal.

HC severely changed the hydrodynamic conditions inside the chamber where it took place. It has to be noted that the hydrodynamic phenomena caused by $\mathrm{HC}$ are modelled by the complex hydraulic models and is the subject of numerous past and current research. ${ }^{33-35}$ The description herein is provided solely for the readers to conceive the matter in an easier way. At the throat of the constriction the calculated $v$ was approx. $40 \mathrm{~m} \mathrm{~s}^{-1}$ (Table 2 ) and $R e$ was approx. $1.02 \cdot 10^{5}$, representing very intensive turbulence. As the flow cross-section increased to the one of the photolytic reactor (Figure $10 \mathrm{~b}$., cavitation zone between Sections 2 and 3), the turbulent effect diminished along the longitudinal axis and returned to plug-flow conditions (Figure 10 b., Section 3), which is typical of the flow without the application of $\mathrm{HC}$. If the Borda-Carnot model was assumed and generalized to this case, the length of the dissipation of the turbulence after the HC generators was approx. 8-10 fold of the difference between downstream and upstream pipe diameter ( $\mathrm{HC}$ generator in this case), before the expansion. ${ }^{32}$

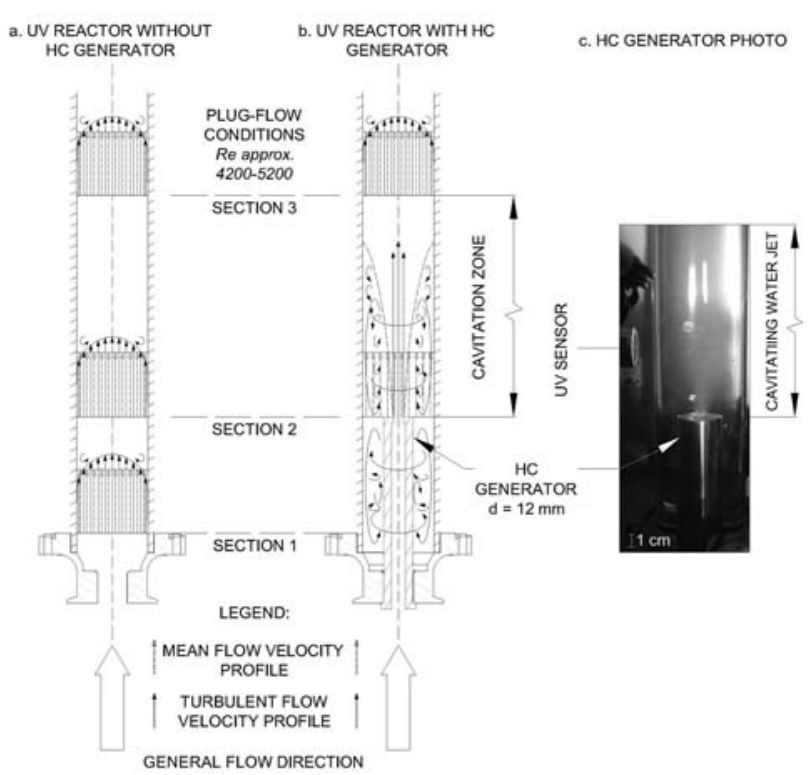

Figure 10. Illustration of flow pattern conditions inside UV photolytic reactor: a. Plug flow conditions throughout the longitudinal axis of the UV reactor (Sections 1-3) without the application of $\mathrm{HC}$; b. Severe radial and counter-current turbulence in Sections 1 and 2 when $\mathrm{HC}$ was applied; c. Photo of the photolytic reactor with the UV lamps removed and a visible HC generator with the cavitating water jet. 
Between Sections 1 and 2 and especially between Sections 2 and 3 in Figure 10 b.), the influence of $\mathrm{HC}$ was expressed in intensive radial and counter-current turbulence. Nevertheless, the mean velocity across the UV reactor in Sections 2 and 3 is maintained the same (mass conservation). The behaviour of such a water flow pattern was obviously improving the mass transfer of $\mathrm{H}_{2} \mathrm{O}_{2}$ related to the reactions in the unevenly distributed UV fluence rate as illustrated in Figure 2. From the results presented in Section 3.1, $\mathrm{H}_{2} \mathrm{O}_{2}$ mass transfer could be improved thereby, especially in the conditions of the relatively high $\mathrm{UVA}_{254}$ and pollutants concentrations (MB and HA).

Related to the influence of $\mathrm{HC}$ on photolytic reactions, Figure 11 displays the UV light fluence rates $E_{o}$ [W $\mathrm{m}-2$ ] at $\lambda=254 \mathrm{~nm}$ during the $\mathrm{MB}$ treatment by $\mathrm{H}_{2} \mathrm{O}_{2} / \mathrm{UV}$ AOPs alone and coupled with HC, measured by the UV sensor in the cavitation zone (Figure 10). Based on the theoretical aspects described by Bolton ${ }^{31}$, for the same (relatively high) range of $\mathrm{UVA}_{254}$ of the matrix $(0.168 \pm$ $\left.0.015 \mathrm{~cm}^{-1}\right)$, lower values of the senor readings in HCcoupled configurations represent the conditions, in which more UV photons were consumed by the water matrix. This implies more reactions of UV with $\mathrm{H}_{2} \mathrm{O}_{2}$ to yield $\mathrm{HO} \cdot$ or the direct photolysis of the pollutants (the other way around, less UV photons reached the UV sensor), which correlates with the higher removal rates of the MB when $\mathrm{HC}$ was applied. Although the differences in the UV sensor readings between $\mathrm{H}_{2} \mathrm{O}_{2} / \mathrm{UV}$ AOPs and these coupled with $\mathrm{HC}$ are only in the range of 5-10\% (Figure 11), this value was sufficient enough to increase the MB decolourization by approx. $15 \%$.

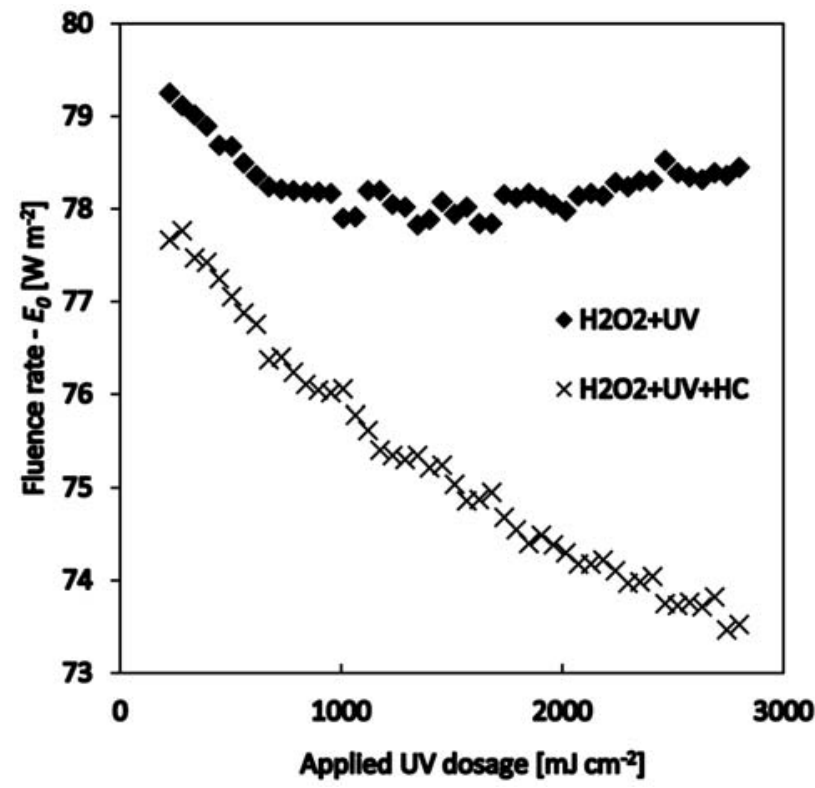

Figure 11. Comparison of the fluence rate readings of the UV sensor for MB decolourization experiments; $\mathrm{H}_{2} \mathrm{O}_{2}$ dosage $=5 \mathrm{mg} \mathrm{L}^{-1}$, $\mathrm{UVA}_{254}=0.168 \pm 0.015 \mathrm{~cm}^{-1}$.
On the opposite side, micropollutants experiments were performed using water matrix with a very low $\mathrm{UVA}_{254}$, i.e. $0.017 \pm 0.02 \mathrm{~cm}^{-1}$. Much higher absolute fluence rate values for these sets of experiments compared to $\mathrm{MB}$ decolourization, in the range of approx. $184-196 \mathrm{~W} \mathrm{~m}^{-2}$ and $73-79 \mathrm{~W} \mathrm{~m}^{-2}$, respectively, are a consequence of low $\mathrm{UVA}_{254}$ (much less UV photons are absorbed by the matrix). As shown in Figure 12 , the sensor readings were practically the same for $\mathrm{H}_{2} \mathrm{O}_{2}$ /UV AOPs alone or these coupled with $\mathrm{HC}$, or the latter were higher. On the grounds explained above, these observations can be correlated to the results of the micropollutants removal, where the application of $\mathrm{HC}$ did not contribute significantly to the overall removal rates.

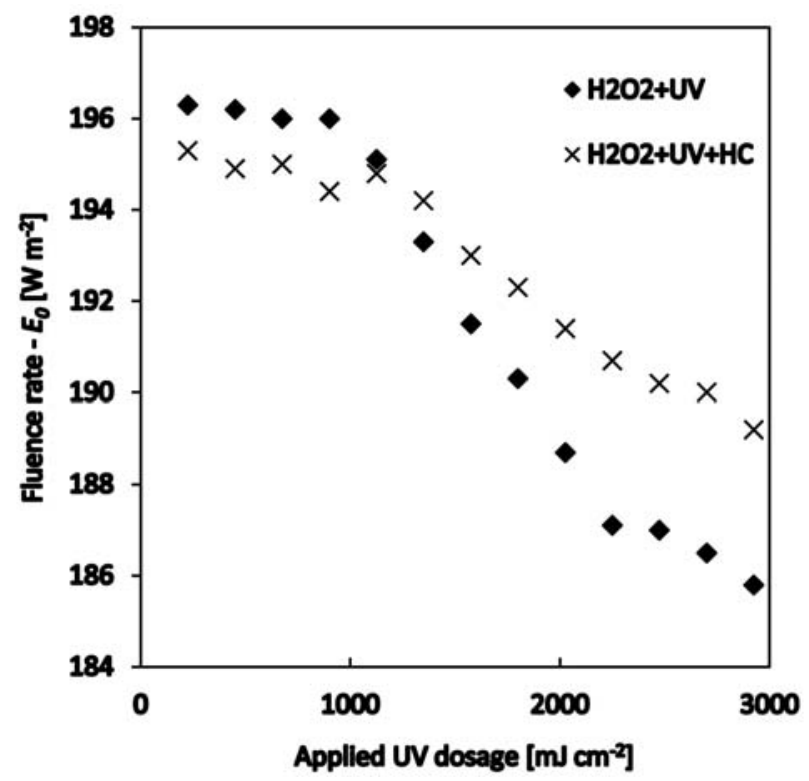

Figure 12. Comparison of the fluence rate readings of the UV sensor for micropollutants removal experiments; $\mathrm{H}_{2} \mathrm{O}_{2}$ dosage $=10 \mathrm{mg}$ $\mathrm{L}^{-1}, \mathrm{UVA}_{254}=0.017 \pm 0.02 \mathrm{~cm}^{-1}$.

\section{6. Energy Efficiency of the Treatment}

To assess the energy efficiency, electric energy per order (or $90 \%$ ) of removal $E_{\mathrm{EO}}\left[\mathrm{kWh} \mathrm{m}^{-3}\right.$ order $\left.^{-1}\right]$ of the selected evaluated parameter was calculated using the term:

$$
E_{\mathrm{EO}}=P \cdot t /\left(V \cdot \log \left(\left[x_{0}\right] /\left[x_{t}\right]\right)\right)
$$

where $P[\mathrm{~kW}]$ is the electrical power consumption of the experimental setup, measured using the power meters installed on the experimental set-up, $x_{0}$ is the initial value of the evaluated parameter $\left(\mathrm{A}_{610}\left[\mathrm{~cm}^{-1}\right]\right.$, DOC $\left[\mathrm{mg} \mathrm{L}^{-1}\right]$, micropollutants concentration $\left[\mu \mathrm{g} \mathrm{L}^{-1}\right]$; Table 1$)$ and $x_{t}$ the 
value of the same evaluated parameter at experiment time $t[\mathrm{~h}]$. The $P$ for the experiments without the application of $\mathrm{HC}$ was $0.73 \mathrm{~kW}$, whereas the $P$ for the HC-coupled experiments was $0.98 \mathrm{~kW}$, including the power consumption of the UV photolytic reactor.

The application of $\mathrm{HC}$ requires additional driving force to reach its adequate conditions compared to $\mathrm{H}_{2} \mathrm{O}_{2} / \mathrm{UV}$ AOPs alone. For comparability, all results of $\mathrm{HC}$ treatment are expressed using an orifice plate with 8 openings $(n=8)$. $\mathrm{UV} / \mathrm{H}_{2} \mathrm{O}_{2}$ AOPs alone could be operated under 1 bar of pressure in the photolytic reactor, whereas the application of $\mathrm{HC}$ to reach $C_{v}$ conditions described in Table 2, required pressures of 6-8 bar at the inlet of $\mathrm{HC}$ generators, thus increasing the energy consumption by approx. $25 \%$ to increase the pressure from the circulation pump. Nevertheless, as provided in Table 6, in the case of the MB decolourization and the DOC removal, $\mathrm{H}_{2} \mathrm{O}_{2} / \mathrm{UV}$ configuration applying $\mathrm{HC}$ as a hybrid process was as energy efficient as the $\mathrm{H}_{2} \mathrm{O}_{2} / \mathrm{UV}$ AOPs alone. In these two cases the overall removal efficiencies were also increased by the application of HC, justifying the additional energy input. On the other hand, micropollutants in general, and especially the contrast agents, were more efficiently removed without the application of HC. Regarding metaldehyde, further research would be required using different geometries of the $\mathrm{HC}$ generators to establish the optimum configuration and possibly reach the same or lower $E_{\mathrm{EO}}$ than for the $\mathrm{H}_{2} \mathrm{O}_{2} / \mathrm{UV}$ AOPs alone.

Table 6. Electric energy per order of removal of the selected evaluated parameter.

\begin{tabular}{lcccc}
\hline $\begin{array}{l}\text { Experi- } \\
\text { mental } \\
\text { configu- } \\
\text { ration }\end{array}$ & $\begin{array}{c}\text { MB } \\
\text { decolouri- } \\
\text { zation } \\
(\boldsymbol{\lambda = 6 1 0 ~} \mathbf{~ n m})\end{array}$ & $\begin{array}{c}\boldsymbol{E}_{\text {EO }}\left[\mathbf{k W h ~ m}^{\mathbf{- 3}} \text { order }^{-\mathbf{1}}\right] \\
\text { acid } \\
\text { removal } \\
\text { (as DOC) }\end{array}$ & $\begin{array}{c}\text { Metal- } \\
\text { dehyde } \\
\text { removal }\end{array}$ & $\begin{array}{c}\text { Contrast } \\
\text { agents } \\
\text { removal }\end{array}$ \\
\hline $\mathrm{H}_{2} \mathrm{O}_{2}+\mathrm{UV}$ & 46.2 & 80.1 & 11.0 & 2.4 \\
$\mathrm{H}_{2} \mathrm{O}_{2}+\mathrm{UV}+\mathrm{HC}$ & 46.6 & 76.7 & 12.0 & 4.0 \\
\hline
\end{tabular}

\section{Conclusions}

The effects of the treatment by $\mathrm{H}_{2} \mathrm{O}_{2} / \mathrm{UV}$ AOPs alone and those coupled with hydrodynamic cavitation on the decolourization of methylene blue solution, removal of dissolved organic carbon from the samples containing humic acid and the removal of metaldehyde, diatrizoic acid and iohexol as micropollutants were investigated. From the conducted research and under herein described conditions, the application of $\mathrm{HC}$ resulted in:

- Increased turbulence throughout much of the plugflow UV reactor (cavitation zone), with much higher dispersion and diffusion in the form of increa- sed radial and counter-current turbulent eddies, thus improving the exposure of the sample to the uneven UV fluence rate distribution at a given cross-section of the reactor in the cavitation zone; - Improved $\mathrm{H}_{2} \mathrm{O}_{2}$ mass transfer and a higher yield of radical species ( $\mathrm{HO} \bullet$ and $\mathrm{HOO} \bullet$ ) that was expressed in the increased removal rate of the investigated organic pollutants.

The potential benefits of the $\mathrm{HC}$ application as a hybrid process to $\mathrm{H}_{2} \mathrm{O}_{2} / \mathrm{UV}$ AOPs were emphasized in the conditions of relatively:

- High UV absorbance (at $\lambda=254 \mathrm{~nm}$ ) and colourization of the matrix, i.e. unfavourable conditions for the efficient fluence rate distribution in the photolytic reactor;

High pollutant concentrations;

Low dosages of $\mathrm{H}_{2} \mathrm{O}_{2}$ and UV;

Low ratio of (photo-) oxidants dosages to pollutant concentration.

Due to the fact that HC enables scale-up from laboratory- and pilot-size to full-scale applications, further research and development of the HC generators geometry and the layout of the installations (optimized hydrodynamic conditions) is possible, yielding potentially more effective hybrid $\mathrm{H}_{2} \mathrm{O}_{2} / \mathrm{UV}$ AOPs for the removal of recalcitrant organic pollutants, especially in the conditions where the UV fluence rate distribution is less favourable. From the challenges awaited along this path, the issues of material wear and durability of the $\mathrm{HC}$ generators as well as the fact that exposure to adequate $\mathrm{HC}$ conditions requires additional energy input and conditions, limited by hydrodynamic parameters that potentially increase the treatment time to induce sufficient number of passes through the system, are among the ones that need to be addressed to increase the efficiency and practicability of this technology in the future. As shown by this study, coupling $\mathrm{HC}$ with $\mathrm{H}_{2} \mathrm{O}_{2} / \mathrm{UV}$ AOPs can be of interest for further research and development and could be transferred to practical or industrial applications.

\section{Acknowledgements}

Operation part financed by the European Union, European Social Fund (Young Researchers from the Economy program by SPIRIT Slovenia - Public Agency for Entrepreneurship, Internationalization, Foreign Investments and Technology of the Republic of Slovenia, Grant P-MR-10/30).

The authors would like to express gratitude to Xylem Services GmbH - Wedeco, Herford, Germany, for providing research facilities and especially to the Wedeco R\&D laboratory team, Mr. Jens Scheideler, Ms. Carolin Meyer, Dr. Jörg Mielcke, Dr. Achim Ried, Mr. Harald Stapel, Mr. Sebastian Besser and others for their valuable contributions. 


\section{References}

1. A. Matilainen, M. Sillanpää, Chemosphere 2010, 80, 351-365. http://dx.doi.org/10.1016/j.chemosphere.2010.04.067

2. A. D. Dotson, V. S. Keen, D. Metz, K. G. Linden, Water Res. 2010, 44, 3703-3713. http://dx.doi.org/10.1016/j.watres.2010.04.006

3. M. Bekbolet, C. S. Uyguner, H. Selcuk, L. Rizzo, A. D. Nikolaou, S. Meriç, V. Belgiorno, Desalination 2005, 176, 155-166.

http://dx.doi.org/10.1016/j.desal.2004.11.011

4. S. Sarathy, M. Mohseni, Water Res. 2010, 44, 4087-4096. http://dx.doi.org/10.1016/j.watres.2010.05.025

5. USEPA, Stage 2 Disinfectants and Disinfection Byproducts Rule, Federal register, vol. 71, Number 18, United States Environmental Protection Agency, 2006.

6. K. Ikehata, M. Gamal El-Din, S. A. Snyder, Ozone Sci. Eng. 2008, 30, 21-26. http://dx.doi.org/10.1080/01919510701728970

7. S. Singh, R. Seth, S. Tabe, P. Yang, Ozone Sci. Eng. 2015, 37, 323-329.

http://dx.doi.org/10.1080/01919512.2014.998755

8. J. Derco, M. Valičková, K. Šilhárová, J. Dudáš, A. Luptáková, Chem. Pap. 2013, 67, 1585-1593. http://dx.doi.org/10.2478/s11696-013-0324-x

9. M. I. Vasquez, A. Lambrianides, M. Schneider, K. Kuemmerer, D. Fatta-Kassinos, J. Hazard. Mater. 2014, 279, 169189.

http://dx.doi.org/10.1016/j.jhazmat.2014.06.069

10. J. C. Crittenden, R. R. Trussell, D. W. Hand, K. J. Howe, G. Tchobanoglous (Ed.): MWH's water treatment: principles and design; John Wiley \& Sons, Hoboken, USA, 2012, pp. 507-643

11. S. Arrojo, Y. Benito, Ultrason. Sonochem. 2008, 15, $203-$ 211. http://dx.doi.org/10.1016/j.ultsonch.2007.03.007

12. E. F. Karamah, S. Bismo, W. W. Purwanto, Ozone Sci. Eng. 2013, 35, 482-488. http://dx.doi.org/10.1080/01919512.2013.820640

13. S. Arrojo, Y. Benito, Ultrason. Sonochem. 2008, 15, $203-$ 211. http://dx.doi.org/10.1016/j.ultsonch.2007.03.007

14. S. Parsons (Ed.): Advanced Oxidation Processes for Water and Wastewater Treatment; IWA Publishing, London, 2004.

15. P. Braeutigam, Z.-L. Wu, A. Stark, B. Ondruschka, Chem. Eng. Technol. 2009, 32, 745-753. http://dx.doi.org/10.1002/ceat.200800626

16 Z.-L. Wu, B. Ondruschka, P. Bräutigam, Chem. Eng. Technol. 2007, 30, 642-648. http://dx.doi.org/10.1002/ceat.200600288

17. S. Raut-Jadhav, V.K. Saharan, D. Pinjari, S. Sonawane, D. Saini, A. Pandit, J. Hazard. Mater. 2013, 261, 139-147. http://dx.doi.org/10.1016/j.jhazmat.2013.07.012
18. K. K. Jyoti, A. B. Pandit, Ultrason. Sonochem. 2003, 10, 255-264. http://dx.doi.org/10.1016/S1369-703X(03)00116-5

19. D. Maslak, D. Weuster-Botz, Eng. Life Sci. 2011, 11, 350358. http://dx.doi.org/10.1002/elsc.201000103

20. K. K Jyoti, A. B. Pandit, Water Res. 2004, 38, 2249-2258. http://dx.doi.org/10.1016/j.watres.2004.02.012

21. S. Semitsoglou-Tsiapou, M. R. Templeton, N. J. D. Graham, L. Hernández Leal, B. J. Martijn, A. Royce, J. C. Kruithof, Water Res. 2016, 91, 285-294. http://dx.doi.org/10.1016/j.watres.2016.01.017

22. K. Ikehata, N. Jodeiri Naghashkar, M. Gamal El-Din, Ozone Sci. Eng. 2006, 28, 353-414. http://dx.doi.org/10.1080/01919510600985937

23. H.-W. Yu, T. Anumol, M. Park, I. Pepper, J. Scheideler, S. A. Snyder, Water Res. 2015, 81, 250-260. http://dx.doi.org/10.1016/j.watres.2015.05.064

24. S.-L. Lee, S.-W. Liew, S.-T. Ong, Acta Chim. Slov. 2016, 63, 144-153. http://dx.doi.org/10.17344/acsi.2015.2068

25. E. J. Rosenfeldt, K. G. Linden, Environ. Sci. Technol. 2007, 41, 2548-2553. http://dx.doi.org/10.1021/es062353p

26. P. Braeutigam, M. Franke, Z.-L. Wu, B. Ondruschka, Chem. Eng. Technol. 2010, 6, 932-940. http://dx.doi.org/10.1002/ceat.201000021

27. S. Arrojo, C. Nerín, Y. Benito, Ultrason. Sonochem. 2007, 14, 343-349. http://dx.doi.org/10.1016/j.ultsonch.2006.06.007

28. M. Franke, P. Braeutigam, Z.-L. Wu, Y. Ren, B. Ondruschka, Ultrason. Sonochem. 2011, 18, 888-894. http://dx.doi.org/10.1016/j.ultsonch.2010.11.011

29. M. Zupanc, T. Kosjek, M. Petkovšek, M. Dular, B. Kompare, B. Širok, M. Stražar, E. Heath, Ultrason. Sonochem. 2014, $21,1213-1221$. http://dx.doi.org/10.1016/j.ultsonch.2013.10.025

30. P. Braeutigam, Z.-L. Wu, A. Stark, B. Ondruschka, Chem. Eng. Technol. 2010, 33, 341-346. http://dx.doi.org/10.1002/ceat.200900434

31. J. R. Bolton, Wat. Res. 2000, 34, 3315-3324. http://dx.doi.org/10.1016/S0043-1354(00)00087-7

32. G. Bollrich (Ed): Technische Hydromechanik Band 1, HussMedien, Berlin, Germany, 2007, pp. 88-241.

33. J. S. Krishnan, P. Dwivedi, V. S. Moholkar, Ind. Eng. Chem. Res. 2006, 45, 1493-1504. http://dx.doi.org/10.1021/ie050839t

34. K. Sampath Kumar, V. S. Moholkar, Chem. Eng. Sci. 2007, 62, 2698-2711. http://dx.doi.org/10.1016/j.ces.2007.02.010

35. V. S. Moholkar, A. B. Pandit, Chem. Eng. Sci. 2001, 56, 6295-6302. http://dx.doi.org/10.1016/S0009-2509(01)00253-6 


\section{Povzetek}

Pitna voda vsebuje organske snovi, zaradi katerih je potrebno le-to v nekaterih primerih dodatno pripraviti, da vzdržujemo njeno ustrezno kakovost in varnost za uporabnike. Pri odstranjevanju modelnih organskih onesnažil smo preučevali souporabo hidrodinamične kavitacije (HC) ter napredne oksidacije $\mathrm{z} \mathrm{H}_{2} \mathrm{O}_{2}$ in UV svetlobo. Vzorci pitne vode so vsebovali huminsko kislino, barvilo metilen-modro ter mikroonesnažila (metaldehid, diatrizojsko kislino in ioheksol). Najprej smo vzorce oksidirali $\mathrm{z} \mathrm{H}_{2} \mathrm{O}_{2}$ (doze med 1 in $12 \mathrm{mg} \mathrm{L}^{-1}$ ) ter UV svetlobo (doze med 300 in $2800 \mathrm{~mJ} \mathrm{~cm}^{-2}$ ), kasneje pa pod istimi pogoji še ob souporabi HC, sprožene s šobo ter zaslonkami z različnim številom odprtin $(4,8$ in 18$)$. Ob souporabi HC se je odstranjevanje huminske kisline izboljšalo za 5-15\%, razbarvanje barvila metilen-modro za 5-20 \% in metaldehida za približno $10 \%$. Predvsem v primerih, ko je bila začetna UV absorbanca vode relativno visoka (več kot $0,050 \mathrm{~cm}^{-1}$ pri valovni dolžini $254 \mathrm{~nm}$ ) ter pri visokem razmerju med koncentracijami onesnažil in dozami uporabljenih oksidantov, je souporaba $\mathrm{HC}$ izboljšala hidrodinamične pogoje v fotolitskem reaktorju, povečala izpostavljenost $\mathrm{H}_{2} \mathrm{O}_{2}$ UV svetlobi ter povečala učinkovitost odstranjevanja izbranih onesnažil, kar kaže obetavna izhodišča za nadaljnje raziskave na tem področju. 